\title{
Mortality rate of silky sharks (Carcharhinus falciformis) caught in the tropical tuna purse seine fishery in the Indian Ocean
}

\author{
François Poisson ${ }^{\mathrm{a}}$, John David Filmalter $^{\mathrm{b}},{ }^{\mathrm{c}},{ }^{\mathrm{d}}$, , Anne-Lise Vernet ${ }^{\mathrm{e}}$, Laurent Dagorn $^{\mathrm{b}}$
}

\author{
${ }^{a}$ Institut Français de Recherche pour l"Exploitation de la Mer (Ifremer), Unité Halieutique Méditerranée (HM), \\ Research Unit "EME" UMR212, B.P. 171, Av. Jean Monnet, 34203 Sète Cedex, France. \\ ${ }^{\mathrm{b}}$ Institut de Recherche pour le Développement (IRD), Research Unit "EME" UMR212, B.P. 171, Av. Jean Monnet, \\ 34203 Sète Cedex, France. \\ ${ }^{c}$ South African Institute for Aquatic Biodiversity (SAIAB), Grahamstown, South Africa. \\ d Department of Ichthyology and Fisheries Science (DIFS), Rhodes University, Grahamstown, South Africa. \\ e Orthongel, 11 bis rue des Sardiniers, 29900 Concarneau, France. \\ *: Corresponding author : François Poisson, email address : francois.poisson@ifremer.fr
}

\begin{abstract}
:
Scientists aboard French purse seine vessels recorded the number and condition of silky sharks (Carcharhinus falciformis) caught during three fishing cruises in the Indian Ocean. A sample of 31 individuals that showed signs of life were tagged with satellite tags to investigate their postrelease mortality. The majority of individuals (95\%) were brought on board using the brailer. Combining the proportion of sharks that were dead $(72 \%)$ and the mortality rate of those released $(48 \%)$, the overall mortality rate of brailed individuals was $85 \%$. Few individuals (5\%) were not brailed as they were entangled and landed during the hauling process. The survival rate of these individuals was high, with an overall mortality rate of meshed individuals of $18 \%$. The combination of these two categories led to an overall mortality rate of $81 \%$. This high value reflects the harsh conditions encountered by sharks during the purse seine fishing process. Consequently, methods that prevent sharks being brought on board are a priority for future investigations, but good handling practices should also be promoted as they could reduce mortality by at least $19 \%$.
\end{abstract}

\section{Résumé:}

Des scientifiques embarqués sur des thoniers senneurs français ont enregistré le nombre ainsi que la condition des requins soyeux (Carcharhinus falciformis) capturés pendant trois campagnes de pêche dans l"océan Indien. Un échantillon de 31 individus, présentant des signes apparents de vie, ont été marqués avec des marques satellites pour estimer leur mortalité après leur remise à l"eau. La majorité des individus (95\%) a été embarquée à bord à l"aide d,une salabarde. En utilisant la proportion des requins morts (72\%) et le taux de mortalité des individus remis à l"eau (48\%), le taux de mortalité global d'individus a été estimé à $85 \%$. Quelques individus (5\%) n"ont pas été embarqués au moyen de la salabarde car emmaillés et remontés avec le filet lors du virage. Le taux de survie de ces individus était élevé, ainsi le taux de mortalité global n"était que de $18 \%$. Pour les deux catégories confondues, le taux de mortalité global s"élève à $81 \%$. Cette valeur élevée reflète la dureté des conditions rencontrées par les requins pendant le processus de pêche. Par conséquent, les méthodes empêchant la mise à bord des requins devraient constituées la priorité des recherches futures. Cependant la mise en œuvre de bonnes pratiques de manipulations devrait aussi être encouragée car elles permettraient de réduire la mortalité d"au moins $19 \%$. 
42

\section{Introduction}

Decreasing trends in many shark populations have been highlighted during the past decade. These trends have largely been attributed to an ever increasing demand for shark fins in Asia but are also a result of targeted shark fisheries as an alternative source of protein as other fish stocks decline (Dulvy et al., 2008). As many shark catches go unreported, efforts have recently focused on obtaining alternative estimates of global shark catches, which overcome reporting issues (Clarke, 2007, Worm et al., 2013). These studies have found that catches were likely four times greater than those reported to the United Nations Food and Agriculture Organisation in 2000, and were estimated to range between 1.44 and 1.77 Million tons.

In light of these findings, there exists a clear need for a reduction in shark mortality, in both target and non-target fisheries. Bycatch can be an important source of mortality, especially among pelagic shark species, which are regularly taken in industrial fisheries targeting tuna (Gilman 2011). These fisheries primarily consist of three gear types, longlines, drifting gillnets and purse seines. The latter gear type appears to have the lowest ratio of elasmobranch bycatch to target catch, usually less than $1 \%$ (Gilman, 2011). However, the global extent of the fishery requires that its impact be assessed.

In tropical tuna purse seine fisheries using fish aggregating devices (FADs), the silky shark, Carcharhinus falciformis, is by far the most commonly caught species and can represent up to $90 \%$ of the elasmobranch bycatch (Gilman, 2011). The current practice aboard European purse seiners is to release sharks and rays that are caught. To date no work has been undertaken to assess the at-vessel mortality or post-release mortality of elasmobranchs in the Indian Ocean tuna purse seine fishery. Without a clear understanding of the at-vessel mortality or post-release survival of discarded individuals, the impact of the fishery cannot be known. As such, the objectives of this study were to quantify the overall mortality rate for silky sharks in this fishery.

\section{Materials and methods}

Fieldwork was conducted by researchers aboard French flagged tuna purse seine vessels operating in the western Indian Ocean in 2011 and 2012. Two trips were made on vessels under normal commercial operation in 2011 (March to June) and a third was conducted on a vessel chartered for research purposes during 2012 (April to May). Fishing operations during this cruise followed normal 
fishing practices. In all cases sharks were caught under normal tuna purse seining operations, but animals were sorted and released following the best possible handling practices (Poisson et al., 2013). Deck operation

Sharks captured during fishing operations either became entangled in the mesh of the purse seine and were removed by the crew as the net was being hauled in or were brought on board at the end of the hauling process, with the rest of the catch. All vessels used a metal hopper into which tunas and sharks were dumped using a large brailer. In the hopper, sharks and other teleost bycatch were rapidly sorted from the tunas by the vessel's crew. The catch then passed to the ships lower deck onto a conveyor belt where it was further sorted by crew members and any remaining bycatch removed. During the first two commercial trips researchers were posted on both the upper and lower deck to recover sharks from both locations. During the chartered cruise in 2012, major effort was made to recover all sharks from the hopper before they passed to the lower deck. When sharks were encountered they were placed aside. The total length of each shark was measured to the nearest centimetre and the sex determined visually.

\section{Landing stages}

As conditions experienced by sharks that are entangled in the net during hauling are likely to be different to those that go through the sacking up and brailing process, separate mortality rates were calculated for the two groups.

\section{Shark condition}

Each shark was assigned a condition status based on visual observations of its vigor. This status ranged from 1 - 4, with each defined as follows: 1) good - very active, biting, kicking; 2) fair - little movement but still clear signs of life; 3) poor - low response to external stimuli; 4) dead - no movement, stiffness, absence of movements or reaction of the nictitating membrane following gentle contact with the eye, loss of vibrant eye colour.

Tagging

Post-release mortality was assessed by attaching pop-up satellite archival tags (miniPATs, Wildlife Computers, Redmond, WA, USA) to sharks that showed signs of life (status 1-3). Once deployed, the tags collected pressure (depth), temperature and light level data. Tags were programmed to release 
after either 100 or 150 days. After releasing from the shark, archived data were transmitted via the ARGOS satellite system. Each tag was rigged with an integrated pressure sensitive guillotine that activated at depths approaching $1800 \mathrm{~m}$. This ensured that the tag would automatically detach from the animal when such depths were reached. Furthermore, the tags were programmed to initiate a release if they recorded a constant depth $( \pm 2 \mathrm{~m})$ for 3 days. Tags were anchored in the dorsal musculature of the sharks, using nylon dart heads.

\section{Determining the fate of tagged shark}

The fate of each tagged shark was determined using depth, temperature and light data received from the tags. A mortality was typically identified by a continuous descent to depths greater than $1600 \mathrm{~m}$. If this pattern was observed directly after the shark was released the mortality was considered to have occurred on the vessel (immediate mortality). Otherwise, it was considered as a delayed mortality. If a tag released prematurely, and was floating at the surface, with no sign of mortality prior to that point, the tether was assumed to have failed and the shark believed to have survived. Similarly, when an animal was recaptured, it was considered to have survived. When a tag did not report any data, the fate of the shark was considered unkwnown. When the record of the tag indicated a period when no light data was collected (tag inside another animal) while depth records continued to vary, immediately preceding the tag floating to the surface, a predation event on either the shark or the tag was considered to have occurred (tag or shark predated).

\section{Establishing the cause of death}

Determining if the cause of death is due to the fishing (or tagging) event or to a natural event (e.g. predation) is very difficult. Sublethal injuries may result from extensive bleeding, internal organ damage and infections (Davis, 2002). Cumulative and severe stress can lead to elevated levels of catecholamine, cortisol and other stress hormones in the blood (Mazeaud et al., 1977) and it is suspected that this could affect key functions (e.g. swimming behavior, feeding, immune system), ultimately leading to death. As such, we decided to adopt the most conservative approach and consider that all observed deaths were due to the capture event. In this way, the post release survival rate would at the very least be under-estimated. In comparison, Hutchinson et al. (2013) only considered mortalities that occurred within 10 days of release to be a result of the fishing event. 
Estimating the at-vessel mortality, the post-release mortality rate and the overall fishery induced

mortality

The different rates were first calculated according to landing stage (LS). The fishery induced mortality per landing stage (LS being either meshed, Mes, or brailed, Bra) was the sum of at-vessel mortality and post-release mortality rate:

$$
M_{L S}=\frac{N_{L S d e a d}+\left(N_{L S a l i v e} \times P_{L S}\right)}{N_{L S t o t}}
$$

Where $\mathrm{N}_{\text {LSdead }}$ is the number of sharks observed dead

and $\mathrm{N}_{\mathrm{LSalive}}$ is the number of sharks observed alive

$\mathrm{N}_{\mathrm{LStot}}$ is the total number of sharks observed

And $\mathrm{P}_{\mathrm{LS}}$ is the proportion of animals that died after release

Mortality rates from the two landing stages were then combined to provide the overall fishery induced mortality rate, considering the relative proportion of individuals observed in each stage. The overall mortality rate $\mathrm{M}$ was defined as:

$$
M=\sum_{L S=M e s, B r a}\left(\frac{N_{L S t o t}}{N_{t o t}}\right) \times M_{L S}
$$

Where $\mathrm{N}_{\text {tot }}$ is the total number of observed sharks.

\section{Results}

A total of 221 silky sharks were caught from 48 fishing sets (866 tons of tuna) made during 91 days at sea, during three cruises. Eighteen sharks were discarded by the crew and could not be observed by scientists and were therefore removed from the study. Additionally, one silky shark (235 cm TL) was caught in a free-swimming school and was considered in the study. As such, this study is based on the 202 silky sharks (50-224 cm TL) that were assessed by the scientists. Eleven (5\%) silky sharks were landed during the hauling (entangled) while 191 (95\%) were brailed. Combining all observations, 54 $\%$ (104) of individuals were females and $46 \%$ males (88), and all except one male (224 cm TL) were immature.

At-vessel mortality rate 
151 Two of the eleven sharks that were entangled were dead (18\%), while 137 of the 191 sharks (72\%)

152 that were brailed were dead.

153 According to the data collected during the first two cruises, the mortality rate of brailed sharks was

154 linked to the location where the individuals were observed. A total of $40 \%$ of the sharks observed on

155 the upper deck were dead as opposed to $73 \%$ from the lower deck. The silky sharks observed on the

156 upper deck were significantly larger than those observed in the lower deck (t-test, $\mathrm{p}<0.01 ; 108.4 \mathrm{~cm}$

157 versus $90.9 \mathrm{~cm})$. No correlation was observed between the number of sharks caught $\left(\mathrm{r}^{2}=0.003 ; n=35\right)$

158 and the catch, nor between the at-vessel mortality rate $\left(r^{2}=0.002 ; n=35\right)$ and the catch.

159 Post-release mortality rate

160 Thirty-one silky sharks showing signs of life were tagged. Four tags did not report (one entangled and

161 three brailed). All of the four sharks that were entangled, and whose tags reported, survived. Eleven of

162 the 23 tagged sharks that were brailed died. Seven sharks died immediately after release and four

163 showed delayed mortality after 2.5, 14, 15 and 35 days (Table 1).

164 Overall fishery induced mortality

165 The fishery-induced mortality for entangled sharks was $18 \%$ while it was $85 \%$ for brailed sharks. As 166 such, the overall fishery induced mortality was $81 \%$.

\section{Discussion}

The incidental capture of sharks has received considerable research attention in the past, however, these studies have focused almost exclusively on longline fisheries (Gilman, 2011), while purse seine fisheries have largely been ignored. Studies in the longline sector have established at-vessel mortality rates in various fisheries and estimations of post-release mortality rates under both commercial

172 (Campana et al., 2009) and experimental longline conditions (Moyes et al., 2006). For juvenile silky sharks caught by pelagic longlines, the at-vessel mortality rate was estimated at 66\% (Beerkircher et al., 2002). This rate appears lower than that found by our study (81\%), which also primarily concerned 175 juveniles. Our rate is similar to that reported by Hutchinson et al. (2013) from a US purse-seiner 176 (84\%) operating in the Western Pacific Ocean. This high value reflects the harsh conditions 177 encountered by sharks during the purse seine fishing process. Captured sharks are exposed to varying 
degrees of physical trauma and physiological stress, including crushing, bruising, external abrasions, wounding and mobility restriction during the brailing phase. This particular phase of the fishing operation can last more than an hour. Our study clearly demonstrates that a high proportion of animals are dead by the time they are brailed on board. Approximately half of the individuals that showed some signs of life suffered major trauma which ultimately caused their death. If a significant reduction of the fishery-induced mortality of silky sharks is to be achieved, solutions will have to be found that prevent sharks from ending up in the sack. This is further demonstrated by the finding that individuals entangled in the seine while it was being hauled showed significantly lower mortality rates. This is not surprising considering that they do not experience these prolonged anaerobic conditions or the crushing weight of the tuna catch in the constricted environment of the sack. Furthermore, these individuals are generally released quickly to minimize any risk for the crew.

Campana et al. (2009) suggested that blue sharks caught on longlines that were in an apparently healthy condition were likely to survive in the long-term if released following appropriate release techniques. Here, a similar conclusion was reached regarding silky sharks. As such, catch and release methods can be considered as an appropriate management strategy to help reduce post-release mortality in this fishery. A booklet giving general guidance on the benefits of releasing sharks and advice on ways of improving the chances of released animals surviving has been developed (Poisson et al., 2012). To date the industry has been very supportive of these measures as they are easy to implement with relatively little expense. Transferring the mitigation methods to the entire fleet by training the crew in these identified good practices, and finally monitoring the implementation of these practices on-board, must be undertaken.

Our results are representative of a particular fishery, the French fleet operating in the Western Indian Ocean, using a hopper which receives brailed fish. The results would not be applicable to fleets that are not equipped with this device and where all the fish contained in the brail is discharged directly to the lower deck by a series of sheet metal chutes. We recommend the use of a hopper as it facilitates the sorting of fish on the upper deck, and even suggest redesigning it to improve the retention of small sharks. 
205

206

207

208

209

210

211

212

213

214

215

216

217

218

219

220

221

222

223

224

225

226

227

The high level of at-vessel mortality illustrates the importance of identifying methods that prevent sharks from ending up in the sack at the end of the hauling process, as these would clearly have greater conservation impacts. Several research efforts have been undertaken, or are on-going, to find methods that would avoid encircling sharks (Dagorn et al., 2012), or would facilitate their release from within the net (Itano et al., 2012).

While the mortality rates reported in this study appear to be high it is worth noting that the contribution of the purse seine fishery to total pelagic shark mortality in the Indian Ocean is believed to be extremely small. The findings of a recent investigation (Murua et al., 2013) suggest that this fishery in fact contributes approximately $3 \%$ to total silky shark mortality, while gillnets represent a far greater source of mortality for this species (approximately 95\%). As such, a reduction in the mortality rate due to the purse seine fishery appears negligible for the silky shark population, with large effort clearly necessary in other fisheries. Recently, Filmalter et al. (2013) found that traditional FADS entangle sharks and could increase the fishing mortality of the fishery by a factor of 5 to 10 . The European fleet has already adopted non-entangling FADs to reduce this impact. However, owing to a general lack of data, the stock status of the silky shark population in the Indian Ocean has not yet been assessed.

\section{Acknowledgements:}

We are very grateful to the French skippers and crews from the MANAPANY, BERNICA, and the TORRE GIULIA for their active collaboration. This project was mainly funded by the ORTHONGEL-IRD project on bycatch mitigation, but also received co-funding by the commission European communities, FP7, Theme 2Food, agriculture, fisheries and biotechnology², through the research project MADE, contract No 210496 and the Bycatch mitigation project of the International Seafood Sustainability Foundation. The manuscript was improved following constructive comments of the reviewer. 


\section{references}

Beerkircher, L.R., Cortes, E., Shivji, M. (2002) Characteristics of shark bycatch observed on pelagic longlines off the Southeastern United States, 1999-2000. Mar. Fish. Rev., 40-49.

Campana, S.E., Joyce, W., Manning, M. (2009) Bycatch and discard mortality in commercially caught blue sharks Prionace glauca assessed using archival satellite pop-up tags. Mar Ecol Prog Ser 387 241-253.

Clarke, S. Use of shark fin trade data to estimate historic total shark removals in the Atlantic Ocean. Punta del Este, URUGUAY, Jun, 2007). City, pp. 373-381.

Dagorn, L., Filmalter, J.D., Forget, F. (2012) Summary of results on the development of methods to reduce the mortality of silky sharks by purse seiners. IOTC-2012-WPEB08-21, Indian Ocean Tuna Commission, Working Party on Ecosystem and Bycatch, Victoria, $6 p$.

Davis, M.W. (2002) Key principles for understanding fish bycatch discard mortality. Canadian Journal of Fisheries and Aquatic Sciences 59, 1834-1843.

Dulvy, N.K., Baum, J.K., Clarke, S., et al. (2008) You can swim but you can't hide: the global status and conservation of oceanic pelagic sharks and rays. Aquatic Conservation-Marine and Freshwater Ecosystems 18, 459-482.

Filmalter, J.D., Capello, M., Deneubourg, J.-L., Cowley, P.D., and Dagorn, L. 2013. Looking behind the curtain: quantifying massive shark mortality in fish aggregating devices. Front Ecol Environ 11(6): 291-296.

Gilman, E.L. (2011) Bycatch governance and best practice mitigation technology in global tuna fisheries. Marine Policy 35, 590-609.

Hutchinson, M., Itano, D., Muir, J., Leroy, B., and holland, K. 2013. Fishery interactions and postrelease survival rates of silky sharks caught in purse seine fishing gear. WCPFC-SC9-2013/EBWP-12: $26 \mathrm{p}$.

Itano, D., Muir, J., Hutchinson, M., Leroy, B. (2012) Development-and-Testing-Release-Panel-Sharksand-Non-target-Finfish-PS. WCPFC-SC8-2012/EB-WP-14, 6 p.

Mazeaud, M.M., Mazeaud, F., Donaldson, E.M. (1977) Primary and Secondary Effects of Stress in Fish: Some New Data with a General Review. Transactions of the American Fisheries Society 106, 201-212.

Moyes, C.D., Fragoso, N., Musyl, M.K., Brill, R.W. (2006) Predicting postrelease survival in large pelagic fish. Transactions of the American Fisheries Society 135, 1389-1397.

Murua, H., Abascal, F.J., Amande, J., Ariz, J., Bach, P., Chavance, P., Coelho, R., Korta, M., Poisson, F., Santos, M.N., and Seret, B. 2013. Provision of scientific advice for the purpose of the implementation of the EUPOA sharks. Final Report. European Commission, Studies for Carrying out the Common Fisheries Policy (MARE/2010/11 - LOT 2) 475 p. http://ec.europa.eu/fisheries/documentation/studies/sharks/index_en.htm [accessed 10 December 2013]

Poisson, F., Séret, B., Vernet, A.-L., Goujon, M., Dagorn, L. (2013) Collaborative research: Development of a manual on elasmobranch handling and release best practices in tropical tuna purse-seine fisheries Marine Policy 44(0): 312-320.

Poisson, F., Vernet, A.L., Séret, B., Dagorn, L. (2012) Good practices to reduce the mortality of sharks and rays caught incidentally by the tropical tuna purse seiners. EU FP7 project \#210496 MADE, Deliverable 7.2., . 30p.

Worm, B., Davis, B., Kettemer, L., et al. (2013) Global catches, exploitation rates, and rebuilding options for sharks. Marine Policy 40, 194-204. 


\begin{tabular}{|c|c|c|c|c|c|c|c|c|c|c|c|}
\hline \# Tag & date & Latitude & Longitude & tonnage & $\mathrm{TL}(\mathrm{cm})$ & sex & state & location & $\begin{array}{c}\text { Fate of tagged } \\
\text { shark }\end{array}$ & days at sea & PRM \\
\hline 94248 & $26 / 03 / 2011$ & $14^{\circ} 06 \mathrm{~S}$ & $44^{\circ} 55 \mathrm{E}$ & 15 & 137 & 1 & 1 & upper & unknown & - & unk \\
\hline 94249 & $26 / 03 / 2011$ & $14^{\circ} 06 \mathrm{~S}$ & $44^{\circ} 55 \mathrm{E}$ & 15 & 137 & $\mathrm{~F}$ & 1 & upper & delayed Mortality & 2 & yes \\
\hline 94244 & 26/03/2011 & $14^{\circ} 06 \mathrm{~S}$ & $44^{\circ} 55 \mathrm{E}$ & 15 & 132 & $\mathrm{M}$ & 3 & upper & $\begin{array}{l}\text { Immediate } \\
\text { Mortality }\end{array}$ & 0 & yes \\
\hline 94246 & 26/03/2011 & $14^{\circ} 06 \mathrm{~S}$ & $44^{\circ} 55 \mathrm{E}$ & 15 & 138 & $\mathrm{~F}$ & 3 & upper & $\begin{array}{l}\text { immediate } \\
\text { Mortality }\end{array}$ & 0 & yes \\
\hline 94245 & $28 / 03 / 2011$ & $13^{\circ} 59 \mathrm{~S}$ & $45^{\circ} 38 \mathrm{E}$ & 12 & 140 & M & 1 & upper & survival & 27 & no \\
\hline $94247^{*}$ & $27 / 03 / 2011$ & $14^{\circ} 12 \mathrm{~S}$ & $45^{\circ} 19 \mathrm{E}$ & 5 & 127 & $\mathrm{~F}$ & 1 & lower & survival & 6 & no \\
\hline $94254 *$ & $02 / 04 / 2011$ & $15^{\circ} 21 \mathrm{~S}$ & $44^{\circ} 46 \mathrm{E}$ & 125 & 155 & I & 3 & Entangled & survival & 13 & no \\
\hline 94255 & $28 / 03 / 2011$ & $13^{\circ} 59 \mathrm{~S}$ & $45^{\circ} 38 \mathrm{E}$ & 12 & 86 & $\mathrm{~F}$ & 3 & lower & survival & 44 & no \\
\hline 94256 & 29/03/2011 & $14^{\circ} 22 \mathrm{~S}$ & $45^{\circ} 34 \mathrm{E}$ & 6 & 112 & M & 2 & lower & $\begin{array}{l}\text { Immediate } \\
\text { Mortality }\end{array}$ & 0 & yes \\
\hline 94257 & $31 / 03 / 2011$ & $15^{\circ} 04 \mathrm{~S}$ & $45^{\circ} 47 \mathrm{E}$ & 10 & 100 & $\mathrm{~F}$ & 2 & lower & delayed Mortality & 15 & yes \\
\hline 94258 & $01 / 04 / 2011$ & $15^{\circ} 16 \mathrm{~S}$ & $45^{\circ} 43 \mathrm{E}$ & 42 & 116 & $\mathrm{~F}$ & 3 & lower & $\begin{array}{l}\text { Immediate } \\
\text { Mortality }\end{array}$ & 0 & yes \\
\hline 94259 & $01 / 04 / 2011$ & $15^{\circ} 16 \mathrm{~S}$ & $45^{\circ} 43 \mathrm{E}$ & 42 & 87 & $\mathrm{~F}$ & 1 & upper & delayed Mortality & 14 & yes \\
\hline 104658 & $01 / 04 / 2011$ & $15^{\circ} 21 \mathrm{~S}$ & $45^{\circ} 25 \mathrm{E}$ & 6 & 98 & $\mathrm{~F}$ & 1 & upper & Recaptured & 22 & no \\
\hline 104659 & $01 / 04 / 2011$ & $15^{\circ} 21 \mathrm{~S}$ & $45^{\circ} 25 \mathrm{E}$ & 6 & 87 & $\mathrm{M}$ & 1 & upper & survival & 36 & no \\
\hline 104660 & 01/04/2011 & $15^{\circ} 21 \mathrm{~S}$ & $45^{\circ} 25 \mathrm{E}$ & 6 & 90 & $M$ & 1 & lower & unknown & _ & unk \\
\hline 104661 & $02 / 04 / 2011$ & $15^{\circ} 21 \mathrm{~S}$ & $44^{\circ} 46 \mathrm{E}$ & 125 & 138 & 1 & 1 & Entangled & unknown & - & unk \\
\hline 104662 & $25 / 05 / 2011$ & $14^{\circ} 33 \mathrm{~S}$ & $42^{\circ} 37 \mathrm{E}$ & 6 & 122 & $\mathrm{~F}$ & 2 & Entangled & survival & 53 & no \\
\hline 104663 & $25 / 05 / 2011$ & $14^{\circ} 15 \mathrm{~S}$ & $42^{\circ} 21 \mathrm{E}$ & 0 & 150 & M & 1 & Entangled & Recaptured & 41 & no \\
\hline 104655 & 25/05/2011 & $14^{\circ} 33 \mathrm{~S}$ & $42^{\circ} 37 \mathrm{E}$ & 6 & 119 & $F$ & 3 & upper & $\begin{array}{l}\text { Immediate } \\
\text { Mortality }\end{array}$ & 0 & yes \\
\hline 98717 & $27 / 05 / 2011$ & $14^{\circ} 16 \mathrm{~S}$ & $42^{\circ} 30 \mathrm{E}$ & 0 & 235 & M & 1 & upper & survival & 45 & no \\
\hline 104665 & $02 / 04 / 2012$ & $6^{\circ} 34^{\prime} \mathrm{S}$ & $54^{\circ} 4^{\prime} \mathrm{E}$ & 5 & 104 & M & 2 & lower & delayed Mortality & 35 & yes \\
\hline 104664 & $02 / 04 / 2012$ & $6^{\circ} 34^{\prime} \mathrm{S}$ & $54^{\circ} 4^{\prime} \mathrm{E}$ & 5 & 114 & $\mathrm{~F}$ & 2 & upper & Recaptured & 41 & no \\
\hline 104667 & $03 / 04 / 2012$ & $6^{\circ} 54^{\prime} \mathrm{S}$ & $54^{\circ} 31^{\prime} \mathrm{E}$ & 2 & 132 & M & 1 & Entangled & $\begin{array}{l}\text { Tag or shark } \\
\text { predated }\end{array}$ & 78 & no \\
\hline 98723 & 03/04/2012 & $6^{\circ} 54^{\prime} \mathrm{S}$ & $54^{\circ} 31^{\prime} \mathrm{E}$ & 2 & 155 & M & 2 & upper & $\begin{array}{l}\text { Tag or shark } \\
\text { predated }\end{array}$ & 50 & no \\
\hline 98724 & 03/04/2012 & $6^{\circ} 54^{\prime} \mathrm{S}$ & $54^{\circ} 31^{\prime} \mathrm{E}$ & 2 & 130 & $\mathrm{~F}$ & 2 & upper & survival & 100 & no \\
\hline 98719 & 03/04/2012 & $6^{\circ} 54^{\prime} \mathrm{S}$ & $54^{\circ} 31^{\prime} \mathrm{E}$ & 2 & 135 & M & 3 & upper & $\begin{array}{l}\text { Tag or shark } \\
\text { predated }\end{array}$ & 3 & yes \\
\hline 98720 & $28 / 04 / 2012$ & $8^{\circ} 39^{\prime} \mathrm{S}$ & $53^{\circ} 30^{\prime} \mathrm{E}$ & 1 & 147 & M & 2 & upper & unknown & - & unk \\
\hline 98727 & $30 / 04 / 2012$ & $8^{\circ} 9^{\prime} \mathrm{S}$ & $56^{\circ} 31^{\prime} \mathrm{E}$ & 40 & 117 & M & 3 & upper & $\begin{array}{l}\text { Immediate } \\
\text { Mortality }\end{array}$ & 0 & yes \\
\hline 104666 & $02 / 05 / 2012$ & $4^{\circ} 58^{\prime} \mathrm{N}$ & $58^{\circ} 45^{\prime} \mathrm{E}$ & 14 & 114 & $F$ & 2 & upper & $\begin{array}{l}\text { Immediate } \\
\text { Mortality }\end{array}$ & 0 & yes \\
\hline 98721 & 03/05/2012 & $4^{\circ} 44^{\prime} \mathrm{S}$ & $61^{\circ} 28^{\prime} \mathrm{E}$ & 18 & 224 & M & 2 & upper & survival & 45 & no \\
\hline 104656 & 06/05/2012 & $7^{\circ} 17^{\prime} \mathrm{N}$ & $60^{\circ} 20^{\prime} \mathrm{E}$ & 0,5 & 104 & 1 & 2 & upper & $\begin{array}{c}\text { Tag or shark } \\
\text { predated }\end{array}$ & 79 & no \\
\hline
\end{tabular}

Table 2: Satellite tag releases of the 31 silky sharks. Tag number, tagging date, tagging location, tonnage of tuna during the set, total length, gender, condition state (1) good-very active behavior, biting, kicking; 2) fair- Little movement but still clear signs of life; 3) poor-low response to external stimuli), location of the animal upon retrieval (upper or lower deck), remarks on the tagging 
result, state of the individual (dead, alive, unknown), days at sea, Post-release mortality (PRM); * individuals considered alive; the short period is due to premature release of the tag. 